\title{
Maritime Boundary Delimitation and Sino- Vietnamese Cooperation in the Gulf of Tonkin (1994-2016)
}

\section{Benoît de Tréglodé}

Translator. David Buchanan

\section{OpenEdition \\ Journals}

Electronic version

URL: http://journals.openedition.org/chinaperspectives/7030

DOI: 10.4000/chinaperspectives.7030

ISSN: 1996-4617

\section{Publisher}

Centre d'étude français sur la Chine contemporaine

\section{Printed version}

Date of publication: 1 September 2016

Number of pages: $33-41$

ISSN: 2070-3449

\section{Electronic reference}

Benoît de Tréglodé, « Maritime Boundary Delimitation and Sino-Vietnamese Cooperation in the Gulf of Tonkin (1994-2016) », China Perspectives [Online], 2016/3 | 2016, Online since 01 September 2017 , connection on 09 January 2020. URL : http://journals.openedition.org/chinaperspectives/7030 ; DOI : 10.4000/chinaperspectives.7030 


\section{Maritime Boundary Delimitation}

\section{and Sino-Vietnamese Cooperation}

in the Gulf of Tonkin (1994-2016)

BENOÎT DE TRÉGLODÉ

ABSTRACT: Since the rapprochement between China and Vietnam in 1991, Beijing and Hanoi have always sought to compartmentalise their territorial disputes. As a result, the upsurge of tensions in the South China Sea since 2011 has only affected their bilateral partnership to a limited extent, as the two countries continue to observe the Gulf of Tonkin agreements that were signed in December 2000, establishing their first maritime border in the waters of the Gulf as well as cooperation in matters of fishing, hydrocarbon exploration, and maritime security. This article intends to take stock of the first 16 years of Sino-Vietnamese cooperation in the Gulf of Tonkin, before exploring the potential progress that could represent the current negotiations between the two states regarding the delimitation of the "mouth" of the Gulf, located off the Paracel Islands.

KEYWORDS: Sino-Vietnamese relations, Gulf of Tonkin, maritime cooperation, peripheral diplomacy, maritime and defence policies of the Socialist Republic of Vietnam, common fishery zone, common exploration and development zone, mouth of the Gulf of Tonkin.

\section{Introduction ${ }^{(1)}$}

$\mathrm{F}$ ollowing a period of calm that began in 1991 with the normalisation of relations between China and Vietnam, bilateral tensions in the South China Sea have well and truly resurfaced. By attempting to maintain its political and economic relationships with Beijing while simultaneously pursuing the defence of its maritime claims, the Socialist Republic of Vietnam (SRV) is tampering with a delicate equilibrium. China is in any event too powerful for Vietnam to confront directly. In the lead-up to the $12^{\text {th }}$ National Congress of the Communist Party of Vietnam (CPV), held from 20 to 28 January 2016, Chinese President Xi jinping issued a clear reminder to Vietnamese leaders of the importance of their common interests, in the hope that maritime disputes over the Spratlys and the Paracels would not overwhelm bilateral relations and reduce them to these tensions alone. The Chinese authorities preferred to highlight the Sino-Vietnamese agreements on the Culf of Tonkin, signed on 25 December 2000, (2) which in their eyes constitute an excellent example of the constructive dynamism of the relationship between the two countries. Based on a corpus of texts and interviews carried out in Vietnam and China, and focusing on the Gulf of Tonkin in particular, this text will analyse the mechanisms and processes at work in the establishment of maritime relations between Vietnam and China.

While for China, the Gulf of Tonkin agreements are the fruit of the new "peripheral diplomacy" (zhoubian waijiao 周边外交) established by the Chinese government in the 1990s, for Vietnam the resumption of negotiations with China was more closely linked to the implementation of the SRV's new maritime strategy. Moreover, faced with a neighbour such as China, with whom it shares a complicated historical relationship, Vietnam has always sought to maintain a balance between policies of cooperation and strategies of defence. In fact, while it may harbour ambitions to develop the resources of a long-neglected maritime space, the SRV government is also compelled to adapt to China's new maritime diplomacy, which seeks systematically to act first and maintain the upper hand. Still, given the uncertain situation in the South China Sea (or East Sea, as the Vietnamese call it), and despite a markedly "nationalist" discourse, it cannot be denied that China and Vietnam are making progress in cooperating on maritime matters. However, one might wonder if such cooperation in the Gulf of Tonkin actually benefits Vietnam's maritime economy and its interests in the South China Sea, or whether it is in fact more useful as a symbol of goodwill for the Chinese government, which hopes to convince the ASEAN nations of its peaceful intentions in the aforementioned sea. To answer this question, it is necessary to compare the various statements of intent and ratified agreements with the reality of sector-specific cooperation in the Gulf of Tonkin.

1. The analysis that follows is that of the author alone, and is not intended to represent the views of IRSEM or the French Ministry of Defence.

2. Ministry of Foreign Affairs of the People's Republic of China, "China and Vienam Initial Agreements on Delimitation of Beibu Bay/Fishery Cooperation," 25 December 2000, www.fmprc.gov.cn/ mfa_eng/wjdt_665385/2649_665393/t15782.shtml (accessed on 11 March 2016). For the full text of the agreement, see: "2000 Agreement between the People's Republic of China and the Socialist Republic of Vietnam on the Delimitation of the Territorial Seas, Exclusive Economic Zones and Continental Shelves of the Two Countries in the Beibu Gulf/Bac Bo Gulf," available online on the website of the Centre for International Law, NUS, Singapore: http://cil.nus.edu.sg/2000/2000agreement-between-the-people\%E2\%80\%99s-republic-of-china-and-the-socialist-republic-ofvietnam-on-the-delimitation-of-the-territorial-seas-exclusive-economic-zones-and-continental-s helves-of-the (accessed on 11 March 2016). 


\section{The context: Chinese peripheral diplomacy and the construction of a "maritime" Vietnam}

\section{Vietnam in the face of China's peripheral diplomacy}

During 1992 and 1993, in the spirit of "peripheral diplomacy," Chinese Prime Minister Li Peng (incumbent 1987-1998) spoke on behalf of his country and suggested to the Vietnamese authorities that border negotiations be resumed, firstly along the land border (the agreement was signed in 1999), and then, for the first time in China's history, at sea, in the Gulf of Tonkin. In its quest for power, China sought overtly to re-establish as soon as possible a partnership along its southern border. To achieve this, the $\mathrm{Chi}$ nese and Vietnamese authorities employed a mixture of diplomacy, commercial exchanges, and displays of military prowess to define the basis of their new, neighbourly relationship.

Although the Gulf of Tonkin was not an area high on Beijing's list of priorities, the decision had the advantage of rebalancing its maritime politics in a less contested region than the one situated in the heart of the South China Sea; indeed, there was no territorial dispute (i.e. contested islands) between Beijing and Hanoi in the Gulf. In doing so, China also gave itself a risk-free way to prove to the other states bordering the South China Sea that it could act in good faith when resolving maritime conflicts. As a result, throughout the 1990s the Chinese authorities took great care over their negotiations with Hanoi in the Gulf of Tonkin, while still retaining the upper hand in the process.

\section{The sea: A new strategic space for Vietnam}

As the 1990s began, Vietnam emerged weakened from a decade marked by its intervention in Cambodia, as well as the drying-up of aid from the Soviet Union and the countries of COMECON. It also had to cope with China's new ambitions in peripheral diplomacy, which would redefine the neighbourly relationship between the two countries. ${ }^{(3)}$ In this regard, Vietnam's renewed interest in maritime issues was intended to counterbalance China's increased influence in the waters of the South China Sea, while simultaneously responding to the opening-up of its economy along with the entry into force of the United Nations Convention on the Law of the Sea (UNCLOS) in November 1994, which Vietnam had ratified four months earlier.

Following the Convention's introduction, the Vietnamese authorities' first reaction was to realign their foreign policy with Asian countries, and with ASEAN member states in particular (Vietnam joined the regional organisation in July 1995). China's new maritime ambitions also prompted the Vietnamese authorities to review the SRV's defence policy. ${ }^{(4)}$

Throughout its history, Vietnam had never truly asserted itself as a major maritime power. Seemingly, its people had always prioritised the country's rice fields over its mountainous areas or its coastline. Overall, Vietnam was considered a continental power that neglected issues related to the maritime sphere. When the Vietnamese Communists seized power in 1954, their priority was not to build a merchant fleet or a navy, but rather the land-based confrontation with the Army of the Republic of Vietnam, established in the South between 1954 and 1975 and supported by the United States. ${ }^{(5)}$ Vietnam's naval and air forces had not experienced the upheavals of war in the twentieth century in the way that the ground forces had, and as a result they failed to develop an independent sense of identity within the Ministry of De- fence. After the wars of Indochina (1946-1954) and Vietnam (1965-1975), the establishment of the Soviet Pacific Fleet in the deep-water port of Cam Ranh in 1979 once again prevented autonomous development of Vietnam's naval forces. By the time the Russian forces withdrew from the country at the start of 1990, the SRV's navy was little more than a shell, barely capable of providing food for its troops in the Spratly Islands (146 $6^{\text {th }}$ Marine Infantry Brigade) and operating in the rivers and along the coastline. ${ }^{(6)}$

Vietnam's irredentist narrative in the South China Sea was revived by the Republic of South Vietnam (1955-1975) and then pursued, after 1975, by the government in Hanoi. (7) When China seized the Paracel Islands (occupied by Saigon's army at the time) on 19 January $1974,{ }^{(8)}$ this was robustly condemned by Hanoi. In order to maintain unity within the socialist camp, Hanoi waited until 30 December 1978, seven days after the Khmer Rouge's attack in the Vietnamese province of Tay Ninh, to publicly assert for the first time its sovereignty over the islands in the South China Sea and to condemn China's encroachment on the Paracel Islands that had been claimed by Vietnam since 1954.

With the opening-up of the economy and introduction of the Doi moi (or "reforms") in 1986, the country's coastline took on an increasing strategic role: henceforth, four-fifths of its foreign trade would be carried out by sea. These developments would have a major impact on the SRV's defence and security policies, which subsequently underwent a profound transformation. The 1991 Paris Peace Accord on Cambodia marked the end of a golden age for the land army, and opened up opportunities for the Navy. In May 1995, Do Muoi, the General Secretary of the CPV from 1991 to 1997, announced in a speech to the Naval College in Haiphong that: "The Vietnamese Navy must be modernised and strengthened in order to be capable of playing a key role in sea combat," as well as defending "sovereignty, national interests, and maritime natural resources, while simultaneously building a maritime economy." (9)

Vietnam's new security context (the end of the alliance with Soviet Union/Russia, entry into ASEAN, integration into the international community) reoriented the country's national defence priorities towards the Navy and Air Force. ${ }^{(10)}$ Until now, the SRV's military command had main-

3. According to certain Vietnamese leaders, this peripheral diplomacy sometimes resembled a return to the "marches policy" that Vietnam experienced under the Nguyen dynasty, before the arrival of the French in Indochina in the nineteenth century.

4. Li Ma, "China and Vietnam: Coping with the Threat of Peaceful Evolution," in Carlyle Thayer and Ramses Amer (eds), Vietnamese Foreign Policy in Transition, Singapore, ISEAS, 1999, pp. 44-67.

5. Qiang Zhai, China and the Vietnam War 1950-1975, Chapel Hill, The University of North Carolina Press, 2000.

6. Carlyle Thayer, The Vietnam People's Army under Doi Moi, Singapore, Institute of Southeast Asian Studies, 1994.

7. Pierre Journoud, "Le poids des représentations dans le processus de modernisation de la marine vietnamienne" (The weight of representations in the modernisation of the Vietnamese navy), Revue d'histoire maritime, PUPS, No. 16, 2012, pp. 187-204.

8. In his brief synthesis on the history of Chinese claims and actions in South China Sea, Sébastien Colin notes that the annexation of the Paracel Islands by Communist China was in fact done in two stages: first in the 1950s with the occupation of the Amphitrite group (corresponding to the northern parts of the Paracels) just after the departure of the Kuomintang troops in 1950 and then on 19 January 1974, with the annexation of the Crescent group (corresponding to the southern part of the Paracels) that Republic of Vietnam had inherited from the colonial France. Sébastien Colin, "Litiges insulaires et enjeux géopolitiques en mer de Chine du Sud" (Island disputes and geopolitical stakes in South China Sea), in Béatrice Giblin (ed.), Les conflits dans le monde. Approche géopolitique (The conflicts in the world: A geopolitical approach), Paris, Armand Colin, 2016, pp. 263-276.

9. Cited by Vu Duong Huan, Ngoai giao va cong tac Ngoai giao (Foreign affairs and actions abroad), Hanoi, Nxb Chinh tri quoc gia, 2015.

10. Carlyle Thayer, Gérard Hervouet, "The Army as a Political and Economic Actor in Vietnam," in Christopher Goscha and Benoît de Tréglodé (eds), Naissance d'un État-Parti. Le Viêt Nam depuis 1945 (The birth of a Party-state:Vietnam since 1945), Paris, Les Indes Savantes, 2004. 
tained a communal spirit of national defence, and condemned the divisions that capitalist countries made between the three armed forces (land, sea, and air). Because of this, naval officers had long worn the same uniform as the other branches of the People's Army of Vietnam (PAVN), and were not encouraged to develop their own esprit de corps. In the mid1990s, the Navy numbered only 42,000 men (out of more than 450,000 troops in the PAVN as a whole), of whom 27,000 belonged to the Marine Infantry and whose chief task was to defend the Spratly Islands. ${ }^{(11)}$ Despite the official re-establishment of Sino-Vietnamese relations at the start of the 1990s, China did not wish to establish a defence partnership with the SRV, or offer security guarantees. As a result, a sense of anxiety prevailed. The "Law of the People's Republic of China on the Territorial Sea and the Contiguous Zone" announced on 25 February 1992, and the deal struck with American oil company Crestone in an area around the Spratlys claimed by Hanoi, were cause for concern among the Vietnamese authorities. To respond to this new challenge posed by the renewal of links with China, the authorities quickly drew up a new naval strategy to defend the country's maritime interests. Although the SRV was not prepared to give in, it nonetheless explored one by one the possibilities of economic cooperation and co-exploitation in certain areas and sectors. Re-establishing links with Southeast Asia, Vietnam in 1994 and 1995 committed, in the wake of most other major ASEAN member states, to a renewal program for its naval facilities, as well as relaunching petroleum production campaigns along its coastline, and reconsidered the strategic nature of the sea, especially where the country's economic development was concerned.

The entry into force of the UNCLOS increased the strategic value of the islands in the South China Sea for China and Vietnam alike, and the latter would go on to make important decisions in every sector relating to maritime issues. In 1998, in a symbolic gesture, it separated the Coast Guard from the Navy, freeing it from its surveillance obligations, which had become more and more onerous due to increased maritime traffic along the coasts and rivers. The SRV also took its first deliveries of naval equipment. ${ }^{12)}$ However, with a few frigates, a handful of helicopters, but no surveillance planes, tankers, or anti-submarine fighter planes, the Navy was still underequipped. In 2006, the Ministry of Defence created a new naval police and naval aviation corps with a few planes at their disposal (the Sukhoi Su-22, Su-27 and Su-30). ${ }^{(13)}$ Naval command knew that in its current state, the Vietnam People's Navy (Hai quan Nhan dan) did not have the capabilities necessary to assure the protection of its islands and islets in the Spratlys, which lay too far from the Vietnamese mainland. (14) In a period when the country was opening up economically, the first priority was given to traditional responsibilities: defending commercial ports, surveillance of territorial waters, protecting the principal shipping routes, and monitoring fisheries. Added to that were a variety of responsibilities at sea, such as fighting illegal fishing in the Exclusive Economic Zone (EEZ), carrying out search and rescue operations, combatting maritime piracy, protecting oil platforms, and fighting pollution, or even strengthening cooperation with the navies of other countries in the region. It would take over a decade before a publicly-released SRV document, the 2010 Third White Paper on National Defence (after ones of 1994 and 2004), formally made the connection between the reorientation of the SRV's naval strategy and the "burdensome presence of our great northern neighbours," the direct consequence of which was that the country had to modernise and develop its naval forces. According to the leaders of the SRV, China and
Southeast Asia would henceforth have to reckon with a "maritime" Vietnam: a new regional power in the South China Sea.

\section{The Gulf of Tonkin agreements (2000)}

The Gulf of Tonkin (Vinh Bac Bo in Vietnamese or Beibu wan 北部湾 in Chinese) covers an area of 126,250 square kilometres, bordered to the west by the north coast of Vietnam, and to the east by the Chinese coastlines of the Guangxi Autonomous Region, the Leizhou Peninsula (in Guangdong Province), and the island of Hainan. For the most part relatively shallow (under 60 metres), the Gulf measures $283 \mathrm{~km}$ at the widest point of its mouth, and $191 \mathrm{~km}$ between the point of Oanh Ca on Hainan, and the Vietnamese island of Con Co. ${ }^{(15)}$

\section{The Gulf of Tonkin and the Franco-Chinese Convention of 1887}

Before the agreement of 2000, administration of the Gulf of Tonkin was covered by the Franco-Chinese Convention of 1887 , which by delineating the "Paris meridian" had attributed 38\% of the Gulf's area to the China's Qing dynasty and 62\% to Annam, at the time a French protectorate. (16) On 26 December 1973, Hanoi, now interested in the economic potential of the Gulf's waters and seabed, made Beijing aware of its intention to carry out oil exploration there, and suggested that China and Vietnam re-delimit their respective zones. Negotiations opened on 14 August 1974 in a situation that was unfavourable to the regime of North Vietnam, since China had just recovered islands occupied by South Vietnam in the Paracels a few months before the Republic fell in April 1975. Hanoi requested the same delimitation set out in the Convention of 1887, but Beijing rejected this, putting forward instead the idea that the division should comply with "international law of the sea," and refusing the legacy of the meridian, a system that dated back to the nineteenth century. In addition, Beijing decided to invoke its "rights," stating unilaterally that half of the Gulf was Chinese, and that it was up to China to determine the rules of the game. (17) In 1976, Beijing took the initiative and organised a campaign to explore the seabed in the Gulf without informing Vietnam. The geopolitical context was strained be-

11. In 1994, the SRV's naval force was notoriously ill-equipped: seven frigates, three sloops-of-war, ten missile-launching patrol boats, 13 motor torpedo boats, 15 minesweepers and minehunters, six amphibious boats, and a handful of small river and coastal patrol boats.

12. The first development contracts had been signed in 1994 with Russian state-owned arms company Rosvooruzheniye.

13. The Su-22 is an updated version of the extremely old Su-17 aircraft. The Su-27 and Su-30 are more modern, ordered by Hanoi in 1995 and 1997 (the Su-27s) and then in 2004, 2011, and 2013 (the Su-30s).

14. Vietnam lays claim to all islets and reefs in the Spratlys, and currently occupies 21 features, at least nine of which are above sea-level at high tide. See Didier Ortolland, Jean-Pierre Pirat, Atlas géopolitique des espaces maritimes (Geopolitical atlas of the oceans), Paris, Editions Technip, 2010.

15. Tran Duc Thanh, Le Duc An, "Nhung net co ban ve dieu kien tu nhien, tai nguyen thien nhien va moi truong Vinh Bac Bo" (The principal characteristics of the natural conditions, resources, and environment in the Gulf of Tonkin), Conference Paper, November 2012, https://www.research gate.net/profile/Tran_Thanh9/publications/4 (accessed on 11 March 2016).

16. It is important to note that this dividing line drawn up in 1887 was not a maritime boundary delimiting sovereignty rights over maritime spaces, but has only served to share the islands within the respective zones, and that even though it was subsequently used several times by the two states for the convenience of exercising some jurisdictional functions. For more details on these points, see Keyuan Zou, "Maritime Boundary Delimitation in the Gulf of Tonkin," Ocean Development and International Law, Vol. 30, No. 3, 1999, pp. 235-254.

17. S. Jayakumar, Tommy Koh, and Robert Beckman (eds), The South China Sea Disputes and Law of the Sea, Cheltenham, Edward Elgar Publishing, 2014. 
tween these two communist neighbours, caught as they were in a bind between Sino-Soviet tensions and, after 1978, the Cambodian crisis. ${ }^{(18)}$ China believed that this was the most effective means of asserting its authority over the Vietnamese in the contested area. The better to persuade Hanoi, China suggested beginning a new round of negotiations in October 1977, but as war drew nearer in 1979, discussions were cut short and shelved indefinitely.

\section{From the resumption of negotiations to delimitation (1994-2000)}

With the rivalry between China and the USSR, and even more so after the brief and bloody Sino-Vietnamese war of February 1979 and the decade of simmering conflict that followed, the waters of the Gulf of Tonkin fell into neglect, and order in the region was disrupted. With the collapse of cooperation from the Soviet Union and the fall of the Berlin Wall in 1989, Vietnam's leaders were finally prompted to make a secretive visit to China to discuss the future. At this stage, the idea of reconciliation between China and Vietnam was still in its infancy, ${ }^{(19)}$ but the economic situation was difficult and it was important to exhibit a sense of pragmatism. When relations between Beijing and Hanoi began to stabilise in 1991, negotiations over the border were resumed. (20) In October 1993, the Chinese and the Vietnamese were able to reach an agreement to "apply international law and adapt to international practices, while taking into account the special circumstances of the Gulf in order to reach an equitable solution." (21) But as China's power grew, the debate over the borderline in the Gulf of Tonkin allowed Beijing to resume its cooperative discourse in matters of maritime security, and to show other states in the region that it could act with good will in geostrategic disputes in the South China Sea. China was determined to lead Vietnam in the same direction. ${ }^{(22)}$ In the eyes of the SRV, the negotiation of a first maritime border agreement with China was inextricably linked to the overall dynamic of its relations with Beijing. Since the departure of the USSR, Hanoi had clearly decided to pursue a policy of active regional integration. As for China, the issue was not a priority, but Chinese diplomats were determined to showcase their intentions in Southeast Asia. In six years, from March 1994 to December 2000, China and Vietnam brought their joint working groups together on 17 separate occasions. The Chinese side suggested dividing up the Gulf equally (with $50 \%$ for each country), in addition to an agreement on the area's fisheries. As for the Vietnamese, they continued to support the division of the Paris meridian of 1887 along with a separate agreement on fishing, given the potential threat posed by the economic clout of China's fisheries. It is unlikely that the Chinese and Vietnamese would have extricated themselves from this new stalemate without the sudden impact of the 1997 Asian financial crisis and its effect on Vietnam. Although it was still only partly integrated into the economy of the region, Vietnam did not escape the upheavals of the Asian crisis. After the euphoria of its return to the international stage (1993-1997), the CPV understood that the country was only one piece of the regional puzzle, and that the model for economic development that Vietnam had lived through as part of the socialist bloc belonged in the past. At the time, certain leaders understood that China's desire to include fishing in the negotiations could provide an early opportunity to restructure a strategic sector of the Vietnamese economy. After five years of talks, the SRV finally relented (in secret) and ceased to consider the Convention of 1887 as the judicial basis for its negotiations with Beijing. Meanwhile, China accepted delimiting the waters of the Gulf via a line that would take into account the presence and position of the islands.

\section{The islands of the Gulf of Tonkin: A major concern for Hanoi}

For the SRV, the question of the islands' status was an important one: the UNCLOS designated an area of water to each of these territories, and these areas were liable to influence the route of the maritime border. ${ }^{(23)}$ Although the dividing-up of the myriad small islands situated in the two nations' territorial waters had been settled during the 1880s, the main issue for Vietnam during the negotiations was to include its two largest Gulf islands in the delimitation process: Con Co to the south, and especially Bach Long Vi, the Gulf's largest island, situated $110 \mathrm{~km}$ off the Vietnamese coast and $130 \mathrm{~km}$ from Hainan. Considered a former Chinese possession, the island of Bach Long Vi was surrendered to French Indochina following the signing of the Franco-Chinese convention of $1887^{(24)}$ before being annexed by the Japanese army during the Second World War. China took back the island in 1955 and then, on 16 January 1957, retroceded it to North Vietnam. The SRV's Decree No.49/Ttg, issued the same day, stipulated that the island of Bach Long Vi was a Xa (or "village") that would henceforth belong to the city port of Haiphong, and established a fish farming co-operative that numbered 93 workers, 22 hectares of land, and 13 ships. (25)

By accepting Hanoi's stance on the issue of the islands, China conformed to a key principle of the Convention on the Law of the Sea, one that it was still under dispute in the rest of the South China Sea. According to certain international observers, China's decision offered hope for the future regarding the balance of security in this maritime zone. (26) Meanwhile, Vietnam agreed to relinquish its initial claim to "historic rights" over the Gulf.

In the end, it was the two states' adoption of the legal framework based on the location of the islands (Bach Long Vi, Con Co, Chang Dong, and Chang Tay on the Vietnamese side, and Bai Su Yan on the Chinese side) that marked

18. Christopher Coscha, "La géopolitique vietnamienne vue de l'Eurasie : quelles leçons de la troisième guerre d'Indochine pour aujourd'hui?" (Vietnamese geopolitics as seen from Eurasia:What lessons can be learned today from the Third Indochina War?), Hérodote, No. 157, $2^{\text {nd }}$ quarter 2015, pp. 23 38.

19. In 1989, the district of Trung Khanh in Cao Bang Province, which borders China, was regularly hit by missiles from the Chinese People's Liberation Army. Interview at the Institute of History, Hanoi, January 2015.

20. Ramses Amer, "China, Vietnam, and the South China Sea: Disputes and Dispute Management," Ocean Development \& International Law, Vol. 45, No. 1, 2014, pp. 17-40.

21. Nguyen Thi Hanh, "Vinh Bac Bo trong Quan he Viet Nam va Trung Quoc: van de va lich su" (The Gulf of Tonkin's role in Sino-Vietnamese relations: Questions and history), Nghien Cuu Lich Su (Historical studies), Vol. 4, No. 444, 2013, pp. 69-79.

22. Keyuan Zou, "Sino-Vietnamese Agreement on Maritime Boundary Delimitation in the Gulf of Tonkin," Ocean Development and International Law, Vol. 36, No. 1, February 2005, pp. 13-24.

23. Article 121 of the UNCLOS does in fact authorise the delimitation of a territorial sea, a contiguous zone, an EEZ, and a continental shelf from the coastline of islands, but only if the island is a "natural" structure and "above water at high tide." See UNCLOS, Article 121 "Regime of islands," www.un.org/depts/los/convention_agreements/texts/unclos/unclos_e.pdf (accessed on 11 May 2016).

24. In his paper published in 1999, Keyuan Zou mentioned that it is unclear whether Bach Long Vi Island was one of the contested areas during the 1887 Sino-French boundary negotiations. He added that boundary line had only attributed the ownership over the coastal islands, but not over the Bach Long Vi Island, which is a mid-ocean island. Keyuan Zou, "Maritime Boundary Delimitation in the Gulf of Tonkin," art. cit., pp. 235-254.

25. Tran Duc Thanh et al. (eds), Thien nhien va moi truong vung bien dao Bach Long Vi (Nature and the environment on the Island of Bach Long Vi), Hanoi, Nxb Khoa hoc Tu nhien va Cong nghe, 2013.

26. Nguyen Hong Thao, Ramses Amer, "The Management of Vietnam's Boundary Disputes," Ocean Development and International Law, Vol. 38, No. 3, July 2007, pp. 305-324. 
the success of Sino-Vietnamese negotiations in the Gulf of Tonkin. On 25 December 2000, an agreement on maritime boundary delimitation was signed in Hanoi, in addition to an agreement on fisheries. The agreement granted $53.23 \%$ of the Gulf's total area to the SRV, and $46.77 \%$ to China. This agreement demarcated the first maritime border between China and a neighbouring country, and was considered by the Vietnamese to be "a major political victory" (Thang loi chinh tri lon) for Vietnamese diplomacy. (27)

Finally - and a detailed account of this is yet to be told - the Gulf of Tonkin agreements created favourable conditions for a more extensive collaboration and a strengthening of ties between the Chinese and Vietnamese provinces that border the Gulf. Two major economic development projects were launched. In July 2006, at Nanning, the government of the Guangxi Autonomous Region held its first forum for economic cooperation in Greater Tonkin (fan Beibu wan jingji hezuo luntan 泛北部湾经济合作论坛), a project that was integrated the following year, with encouragement from the Chinese central authorities, into the development plan proposed by Vietnam for "Two corridors and one economic circle in the Gulf of Tonkin" (Hai Hanh Lang va Mot Vong Tron Kinh Te). In other words, the agreements on land and maritime borders between China and Vietnam signalled the start, as the new millennium began, of a new zone of cooperation and economic development around the Gulf of Tonkin. (28)

\section{Sector-specific cooperation}

The Gulf of Tonkin agreements also outlined a series of cooperative actions in specific sectors. The two countries set up joint projects for protecting the marine environment, managing fish stock, and even scientific research. They also organised joint patrols of their coastguards, navies, and maritime police to carry out joint search and rescue exercises, or to combat natural disasters (Humanitarian Assistance and Disaster Relief, or HADR). (29) To achieve this, China and Vietnam "created joint management committees, nominated teams of experts, and launched studies of the area in line with the priorities for common action established by the two states in the Gulf." (30) While Vietnam entered these talks with modest ambitions, China's main aim was to reduce disputes between Chinese and Vietnamese fishermen, and to use this first maritime border agreement as a public display of its policy in Asia. The goal was to show that China could hold a dialogue and make compromises, and that criticisms over its inability to deal bilaterally with problems in the South China Sea were unfounded. But if the establishment of a new, practical Sino-Vietnamese partnership in the Gulf of Tonkin represented a step forward, the risk nevertheless remained that the agreement would have little effect in the shortto-medium term. Looking back, in light of the initial hopes for the project, we can attempt to describe what, in the end, has been achieved in terms of cooperation between China and Vietnam in the Gulf of Tonkin since the year 2000. (31) In fact, it appears that the majority of Sino-Vietnamese achievements are related to economic exploitation of the sea, with fishing and the joint fishing zone on one side, and hydrocarbons and the formation of a common exploration and development zone on the other. ${ }^{(32)}$ In addition, one might also mention the establishment of so-called security operations in the Gulf, shared by the maritime police, coast guards, and navies of both countries.

\section{The fishery agreement}

On the fishery issue, the SRV made no secret of its concern that the agreement might force fishing fleets of wildly differing capabilities into an uneasy coexistence. (33) For Vietnam, fishing occupies an important place in the economy, as much in terms of revenue (7\% of GNP and $40 \%$ of animal proteins consumed in the country in 2013) as in terms of jobs created (4.5 million jobs, also in 2013). In 1997, the Vietnamese government launched a plan entitled Program of Offshore Fishing, which was aimed at making the transition from small-scale fishing, mostly along the coast, to a more industrialised fishing process on the high seas. To achieve this, the state reformed its fisheries using the model developed by China during the 1990s, with more powerful, centralised companies using larger boats. With this in mind, the plan recommended progressively abandoning boats with less than 20 horsepower, and replacing them with ships of 90 horsepower or more. Governmental forecasts are predicting a 64-46\% split in favour of high seas fishing by the year 2020. (34) In 2009, the Vietnamese National Assembly ratified the law on militias and self-defence forces which (just as it did in China) allowed local authorities in coastal and insular areas to form maritime militias, and permitted fishing vessels to use self-defence forces. Four years later, in 2013, the government inaugurated a surveillance centre for sea fishing resources. This centre was equipped with 3,000 high-seas fishing boats and satellite systems managed from control centres in Hanoi and Haiphong for the northern waters corresponding to the Gulf of Tonkin, and in Da Nang and Vung Tau for the southern waters, at the heart of which lie the Spratlys. Once and for all, Vietnam made the transition to industrialscale exploitation of its maritime space. ${ }^{(35)}$

The first section of the fishery agreement established a common fishery zone between China and Vietnam in the Gulf of Tonkin (see Map 1). Six series of talks were necessary before the Vietnamese side (which was not without its own internal debates) came to agree with Beijing not only on the shape this zone would take, but also on the cooperation in terms of protection of the marine environment, as well as on the establishment of a "durable partnership for exploiting aquatic resources in the Gulf," and a whole series of technical cooperative actions and submarine oceanographic research. ${ }^{(36)}$

Situated on either side of the maritime border in the two states' respective EEZs (see Map 1), the common fishery zone is supervised by an ad hoc co-

27. In May 2015, the Diplomatic Academy of Vietnam and the Research Fund for Studies on the East Sea (South China Sea) held a conference in Ha Long (in Quang Ninh Province) entitled "Strengthening Cooperation Between Vietnam and China in the Gulf of Bac Bo," which sang the praises of this diplomatic success story.

28. Daisuke Hosokawa, "Pan-Beibu Gulf Economic Cooperation: China's New Initiative in Cooperation with ASEAN," Osaka Keidai Ronshu, Vol. 60, No. 2, July 2009, pp. 67-78.

29. The 11th joint fishing patrol in the Gulf took place in April 2016, lasting five days and involving two maritime police ships from both sides. It is interesting to note that the event was heavily publicised in China, while the Vietnamese authorities preferred not to draw too much attention to the subject. See "China and Vietnam Began their 11th Joint Fishery Patrol in the Beibu Gulf on Tuesday," Xinhua, 19 April 2016, http://news.xinhuanet.com/english/2016-04/19/c_135293 813.htm (accessed on 8 August 2016)

30. Interview at the Border Committee (Ministry of Foreign Affairs), Hanoi, November 2015.

31. Minjiang Li, "Reconciling Assertiveness and Cooperation? China's Changing Approach to the South China Sea Disputes," Security Challenges, Vol. 6, No. 2, winter 2010, pp. 49-68.

32. Nathalie Fau, "La maritimisation de l'économie vietnamienne : un facteur exacerbant les conflits entre le Viêt Nam et la Chine en mer de Chine méridionale" (The maritimisation of the Vietnamese economy: A factor exacerbating conflicts between Vietnam and China in the South China Sea), Hérodote, No. 157, 2nd quarter 2015, pp. 39-55.

33. Interview at the Institute for Military Strategy (Ministry of National Defence), Hanoi, November 2015.

34. Le Hong Hiep, "Vietnam's South China Sea Disputes with China: The Economic Determinants," The Korean Journal of Defense Analysis, Vol. 26, No. 2, 2014, pp. 175-191.

35. Interview at the Academy of Social Sciences, Hanoi, November 2015.

36. The text of the 2000 agreement states that since the Gulf of Tonkin is a semi-enclosed sea, "the states bordering the Gulf are obliged under international law to cooperate in the preservation and management of its fishery resources." 


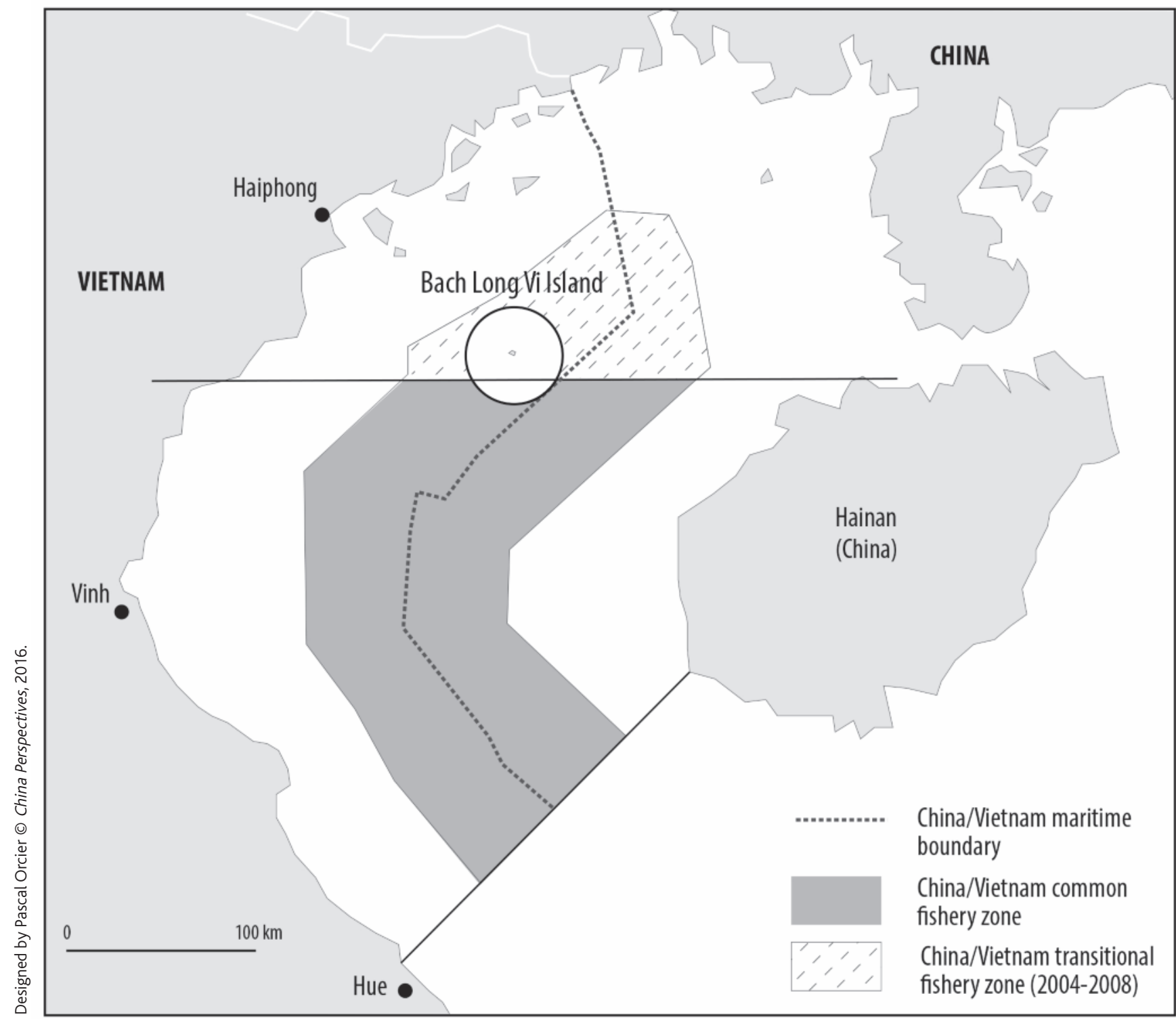

Source: Nguyen Hong Thao, "Maritime Delimitation and Fishery Cooperation in the Tonkin Gulf," Ocean Development \& International Law, Vol. 36, No. 1, 2005, p. 26.

ordination committee whose powers were set out in the agreement. ${ }^{(37)}$ This committee is in charge of fishing authorisations, of fixing annual fishing quotas (determined on the basis of joint studies into the availability of fishery resources), and dealing with conflicts between small-scale fishermen. The committee's other task is to combat illegal fishing that takes place outside the common fishery zone, or that does not respect the fixed quotas. In 2004, after the agreement had been ratified by both countries, a Joint Fisheries Committee (JFC) was also created. ${ }^{(38)}$ It includes representatives from fisheries departments of the ministries of trade and agriculture in both countries, from their ministries of foreign affairs and public security, from their border protection agencies, and from their navies. In theory, the JFC is supposed to meet once a year in order to take stock of what had been achieved. Since then, the Committee's annual meeting has occupied a central place in the coordination and management of fishing activity in the common zone. It is also within the JFC that other forms of cooperation set out in the agreement are discussed: the protection of certain species of fish, the monitoring of piscicultural resources, and the preservation of the marine environment.
But in fact, and despite the organisation's stated aims, the JFC meetings took the form of relatively rigid political rituals, yielding few results. (39) The Committee was controlled by representatives from the police, armed forces, and ministries of foreign affairs, and focused primarily on aspects of security and diplomacy. Exchanges between Chinese and Vietnamese scientists on matters of oceanographic research did take place, but only outside the JFC. ${ }^{(40)}$ As such, the fishery agreement is at the root of a new informal network of scientific exchanges on marine and oceanographic matters between specialised institutes in

37. Li Jianwei and Chen Pingping, "China-Vietnam Fishery Cooperation in the Gulf of Tonkin Revisited," in Tran Truong Thuy (ed.), The South China Sea:Towards a Region of Peace, Security and Cooperation, Hanoi, Diplomatic Academy of Vietnam and The Gioi Publishers, 2011, pp. 303-317.

38. Interviews at the University of Macau and University of Hong Kong, Macau and Hong Kong, November 2015.

39. Interview at the Academy of Social Sciences, Hanoi, November 2015.

40. Jesper Raakjaer, Dao Manh Son et al., "Adaptive Fisheries Management in Vietnam: The Use of Indicators and the Introduction of a Multi-disciplinary Marine Fisheries Specialist Team to Support Implementation," Marine Policy, No. 2, March 2007, pp. 143-152. 


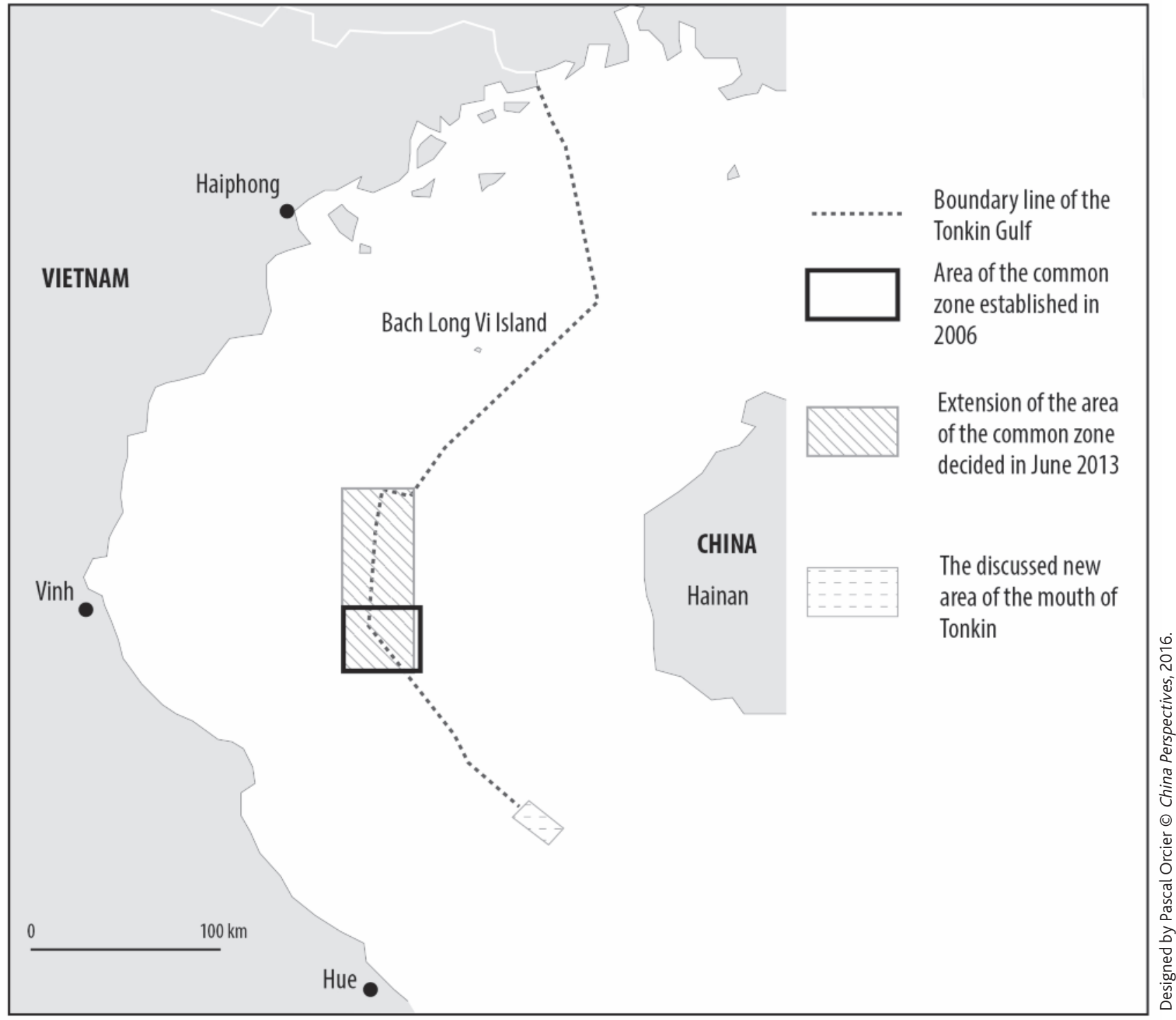

Source: "Petrovietnam va CNOOC da ky ket Thoa thuan sua doi lan 4 Thoa thuan Tham do Chung Viet Nam - Trung Quoc trong Vinh Bac Bo" (PetroVietnam and CNOOC held talks for a fourth update of their agreement on the Sino-Vietnamese common exploration zone in the Gulf of Tonkin), PetroVietnam website, 20 June 2013 ,

https://www.vpi.pvn.vn/vn/ViewNews.aspx?gid=1\&ld=930 (accessed on 27 June 2016); "Viet-Trung khao sat chung vung bien ngoai cua Vinh Bac Bo" (Vietnam and China join forces to explore the area in the mouth of the Gulf of Tonkin), Vietnam Net, 19 December 2015, http://vietnamnet.vn/vn/thoi-su/279873/viet-trung-khao-sat-chung-vungbien-ngoai-cua-vinh-bac-bo.html (accessed on 27 June 2016).

China and Vietnam (for the most part based in Haiphong for the Vietnamese, and in Hainan for the Chinese side). Although it came rather late, the realisation by Vietnamese and Chinese scientists of the importance of controlling their marine assets has brought about a kind of "academic diplomacy." In Vietnam and in China these channels are becoming increasingly influential, because they are used by the states to gauge the positions of either side on sensitive matters during semi-official meetings led by researchers (track 1,5).

\section{The common exploration and development zone, and its limits}

The creation of an exploration and development zone shared between the national oil companies (CNOOC and PetroVietnam) constitutes the second major economic issue arising from the Gulf of Tonkin agreements. (41) Preserving the integrity of the defined maritime areas is not incompatible with the existence of a common economic zone, at least as far as the texts are concerned. The 1982 Montego Bay Convention states that joint exploitation of the seabed does not necessarily mean relinquishing the right to sovereignty. China believes that the proliferation of these zones offers a solution that could help to pacify its relations with the states of Southeast Asia. ${ }^{(42)}$

41. Robert Beckman, Clive Schofield, lan Townsend-Gault, Tara Davenport, and Leonardo Bernard, "Moving Forward on Joint Development in South China Sea," in Robert Beckman, Clive Schofield, lan Townsend-Gault, Tara Davenport, and Leonardo Bernard (eds), Beyond Territorial Dispute in the South China Sea: Legal Frameworks for the Joint Development of Hydrocarbon Resources, Camberley, Edward Elgar Publishing, 2013, pp. 312-331.

42. Nathalie Fau, "Les zones communes de développement : une solution au conflit en mer de Chine méridionale ?" (Common development zones: A solution to maritime conflict in South China Sea?), L'Asie du Sud-Est 2016 (2016 Southeast Asia), Bangkok, Paris, IRASEC - Les Indes savantes, 2016, pp. 71-87. 
Deng Xiaoping (leader of China from 1978 to 1992) supported this idea from the late 1970 s onwards.

In 2004, China and Vietnam created a common hydrocarbon deposit exploration zone covering an area of 1,541 square kilometres in the centre of the Gulf of Tonkin (see Map 2). Article 7 of the Gulf of Tonkin Agreement states that if commercially viable deposits located across the delimitation line are discovered, China and Vietnam will use their oil companies as intermediaries in order to reach an agreement on how best to exploit them together. ${ }^{(43)}$ In June 2013, even as the SRV protested against Beijing's "assertiveness" into the South China Sea, PetroVietnam discreetly renewed and extended its agreement with $\mathrm{CNOOC}$, expanding the area of the Gulf's common exploration zone from 1,541 square kilometres to 4,076 square kilometres (see Map 2).

The two countries' oil firms - national companies run by close affiliates of the political decision-makers in Hanoi and Beijing - organised an initial joint exploration campaign in the Gulf, starting in 2006. Little is known about the running of the campaigns that followed, or whether they even took place at all. While both sides seemed to agree on the matter, the conditions of the agreement remained difficult to put into practice. For both PetroVietnam and $\mathrm{CNOOC}$, the political implications of the joint exploitation of oil or gas deposits found in the common zone are, according to certain sources, "practically impossible," as the media fallout from such an operation could have potentially serious political consequences, fuelled by patriotic sentiment from the countries' populations. ${ }^{(44)}$ While the governments in Hanoi and Beijing have committed to jointly exploiting the hydrocarbon deposit exploration zone, certain Vietnamese officials fear a potential discovery of such deposits, "because public opinion is not ready to accept this in either country." (45)

\section{The establishment of security cooperation}

The third, lesser-known section of the Sino-Vietnamese agreements concerns the establishment by China and Vietnam of a cooperative relationship in the realms of defence and security within their common waters. Throughout the 1990s, as fish stocks became increasingly scarce and maritime flows grew stronger, clashes between Chinese and Vietnamese fisheries multiplied. Taking this into account, the most sensitive section of the fishery agreement describes the conduct of joint patrols, carried out by Chinese and Vietnamese maritime police in the common fishery zone. ${ }^{(46)}$ Vietnam's leaders decided to follow China's example in the sensitive matter of security cooperation, but the SRV did not wish to act too ambitiously. Since then, despite obstacles and reluctance on both sides, 19 joint surveillance patrols have been organised between 2006 and 2015, but only in the form of a single annual exercise of limited scope.

The agreement also envisages the enactment of joint exercises between the navies and coast guards of both countries in order to combat piracy, reinforce state actions at sea (such as search and rescue exercises), and protect the common oil exploration zone. Starting in 2006, the first joint surveillance patrols were deployed by navies and coast guards. ${ }^{(47)}$ But, as was the case for the fishery zone, the exercise remained "mostly a symbolic one." (48) For the navy, the exercise only took place once per year, over just two or three days, and on average only involved two or three ships from either side. Each session was followed by a post-exercise debriefing session, but according to one participant, these meetings remain very formal. (49) Within the navy, many people were loath to get involved in this initiative, because, they said, of the "lack of clarity of the directives from central authorities." (50) To date, nine annual sessions have taken place, with the exception of 2014, the year of the oil platform crisis in the Paracel Islands, when naval leaders on both sides decided it was preferable to cancel the exercise. ${ }^{(51)}$ As far as the coast guard is concerned, the joint patrols are more frequent - two per year - and a greater number of boats are involved, with an average of 19 on either side; and as with the maritime police and the navy, a debriefing session is held afterwards to evaluate the exercise.

As the discourse of the Chinese leaders clearly states, one of the objectives of "peripheral diplomacy" is to reinforce channels of communication in every sector, but especially so where security is concerned. Differences of opinion resulting from the historical and geographical specificities of each country may occur, but the main goal is that exercises and exchanges of this type can be reproduced with other Asian countries. In another, albeit modest sense, the fact that the Sino-Vietnamese joint exercises exist is sufficient to meet the objectives set by the agreements of 2000 , and the expectations of Beijing in particular. The limited number of measures taken to combat piracy in no way obliges the two states to commit to any more concrete form of operation at sea. It seems that China hopes, above all, to use this zone of experimentation in the Gulf as a sounding board for its own interests in the South China Sea. By way of example, the Chinese and Vietnamese coast guards have for years been suggesting the enactment of HADR exercises in the Gulf of Tonkin: the decision is a political one, and so far it has not been taken by those at the top. Officially, the Vietnamese and Chinese authorities are congratulating one another on the advances made by their cooperation in the Gulf of Tonkin since 2000, but the real issue seems to be elsewhere, further south in the mouth of the Gulf.

\section{The new negotiations over the "mouth of the Gulf of Tonkin"}

Throughout the year 2010, as tensions rose once more in the South China Sea, China suggested to the Vietnamese authorities that new border negotiations should be held over the "mouth of the Gulf of Tonkin."The fact that China's diplomats were paying attention to this new zone, which borders the Paracel Islands, was a cause for enthusiasm among certain international experts. ${ }^{(52)}$

43. "If any single petroleum or natural gas structure or field, or other mineral deposit of whatever character, extends across the delimitation line defined in Article II of this Agreement, the two Contracting Parties shall, through friendly consultations, reach agreement as to the manner in which the structure, field or deposit will be most effectively exploited as well as on the equitable sharing of the benefits arising from such exploitation" (Article 7). See "2000 Agreement between the People's Republic of China and the Socialist Republic of Vietnam on the Delimitation of the Territorial Seas, Exclusive Economic Zones and Continental Shelves of the Two Countries in the Beibu Gulf/Bac Bo Culf," art. cit.

44. Interview, Hanoi, November 2015.

45. Interview, Hanoi, November 2015.

46. M. J.Williams, "Will New Multilateral Arrangements Help Southeast Asian States Solve Illegal Fishing?", Contemporary Southeast Asia, Vol. 35, No. 2, 2013, pp. 258-283.

47. Lida Masafumi, "New Developments in China's Policy in South China Sea," NIDS Security Studies, No. 9, December 2008, pp. 3-16; Tomotaka Shoji, "Demarcation and Territorial Problems between Vietnam and China," NIDS Security Studies, Vol. 8, No. 3, March 2006, pp. 53-67.

48. Interview, Hanoi, November 2015.

49. Interview, Hanoi, November 2015.

50. Interview, Hanoi, November 2015.

51. François Guillemot and Laurent Gédéon, "Vietnam. La nouvelle donne géopolitique" (Vietnam: The new geopolitical order), L'Asie du Sud-Est 2015 (2015 Southeast Asia), Bangkok, Paris, Irasec - Les Indes savantes, 2015, pp. 315-340.

52. Stein Tønnesson, "Could China and Vietnam Resolve the Conflicts in the South China Sea?", in Yannhuei Song and Keyuan Zou (eds), Major Law and Policy Issues in the South China Sea: European and American Perspectives, Farnham, Ashgate, 2014, pp. 207-244; Ramsès Amer and Keyuan Zou (eds), Conflict Management and Dispute Settlement in East Asia, Farnham, Ashgate, 2011. 
According to these experts, this was evidence of China's willingness to work towards resolving conflicts in the South China Sea. In fact, by bringing a sensitive area into play, Beijing was above all attempting to prevent Vietnam from becoming too close to the Philippines, and to convince ASEAN of its goodwill on maritime issues. In this respect, the greatest feat of the Gulf of Tonkin agreements was to offer China and Vietnam an official framework that allowed them to discuss "the extension of their maritime borders in the mouth of the Tonkin Gulf, intended to deal with incidents between fishing boats in a zone that is contested by both states." (53)

The area concerned (see Map 2) could, in future, represent a new zone of joint exploitation situated outside the waters of the Gulf of Tonkin. With the utmost discretion, groups of experts from both countries met seven times between 2010 and 2011, and from 2012 onwards, the exchanges moved from being "among experts" to "official" status. Officially, China wished to demarcate the waters of this "annex" to the Gulf of Tonkin and, in line with the model for what was achieved in the Gulf, eventually to establish a system of joint cooperation with Vietnam. But from 2013 onwards, repeated tensions in the South China Sea disrupted the schedule of meetings. The Chinese and Vietnamese joint working groups began to meet only once a year, alternating between the countries' respective capital cities. According to one Vietnamese observer, the bilateral discussions on "the mouth of the Gulf of Tonkin" became extremely blunt, and the debate has barely progressed at all in the last two years. ${ }^{(54)}$

For China, opening up this new area of negotiation with Vietnam represents a challenge, because it was pushing the SRV into a maritime dispute without explicitly mentioning the idea of a common zone (of exploration and development) in the "mouth of Tonkin" due to the zone's proximity to the Paracel Islands. Beijing's goal is to force Vietnam to adapt to its initiatives in maritime diplomacy, and to keep the upper hand. Based simultaneously on a specious form of goodwill (the success of negotiations over the "mouth of Tonkin" is far from assured), which would mean isolation for Vietnam if it refuses, and a strengthening of dialogue with the very same country, the promotion of this new space for maritime cooperation benefitted Beijing's policy with ASEAN. ${ }^{(55)}$ President Xi Jinping then clearly confirmed that the future of Sino-Vietnamese relations - and therefore to a certain extent, that of peace in the South China Sea - depended on continued negotiations between the two states over the "mouth of Tonkin," (56) even if, when it came to bilateral diplomatic exchanges, the state of discussions might lead one to believe that Beijing had only opened this new negotiation space with Vietnam in order to leave things as they were. The Gulf of Tonkin agreement is evidence of China's goodwill in maritime cases, and its diplomats take every opportunity to confirm this. Besides, Chinese leaders are already talking about the project to expand China's cooperation in the Gulf of Tonkin to a wider area: that of its "One Belt One Road" initiative (yi dai yi lu一带一路). ${ }^{(57)}$ Hanoi now fears that the convoluted nature of its many agreements with China, or the integration of the SRV into increasingly broad regional agreements, can only lead to a marginalised position detrimental to its own interests.

\section{Conclusion}

The first assessment one might make of the first 16 years of Sino-Vietnamese cooperation in the Gulf of Tonkin - from 2000 to 2016 - is in the end relatively limited in terms of tangible achievements in the sectors of economy (fishing, hydrocarbons) and security (joint exercises). As far as

China's new peripheral diplomacy is concerned, despite the latest tensions arising over the Paracels and the Spratlys, the Gulf of Tonkin agreement still offers Xi Jinping's country a means of resuming its cooperative discourse regarding maritime security and, above all, of initiating new bilateral discussions with the state that borders "its" southern sea. But Vietnam is still obliged to adapt to the Chinese agenda. For the moment, Beijing considers the Gulf of Tonkin, and by extension the Gulf's "mouth," to be a zone of experimentation for its maritime diplomacy in Southeast Asia. It is also an opportunity to test out new forms of dialogue and to gauge how much the other partner is likely to resist. Meanwhile, the leaders of the SRV are holding their country in an ambiguous grey area with regard to Beijing, which may not turn out to their advantage. In this respect, the multifarious strategies that China has developed in the Gulf of Tonkin, without collaboration from any other country, represent an aspect of Beijing's maritime policy that is worrying for Vietnam. It is possible that China's diplomatic activism under $\mathrm{Xi}$ Jinping is above all a seduction tactic, firstly toward the Vietnamese, but also toward all the countries of ASEAN, in order to keep its new partners within reach while still continuing to strengthen its position unilaterally in the South China Sea.

\section{Translated by David Buchanan.}

IBenoît de Tréglodé is director of research at the Institute for Strategic Research (IRSEM), a member of CASE (Southeast Asia Centre, EHESS-CNRS), and was previously director of the Research Institute on Contemporary Southeast Asia (IRASEC) in Bangkok. IRSEM, 1 place Joffre, 75700 Paris SP 07 (bdt.asie@gmail.com).

Manuscript received on 11 March 2016. Accepted on 21 June 2016.

53.

56. "China and Vietnam agreed to launch joint maritime inspections on the waters outside the mouth of the Beibu Gulf in December (...) The inspection can be seen as an important threshold for further maritime cooperation between the two countries (....)." See Xing Zhigang and Chen Mengwei, "China, Vietnam Agree on Joint Inspections," China Daily, 7 November 2015, www.chinadaily .com.cn/world/2015xivisitvs/2015-11/07/content_22394307.htm (accessed on 8 August 2016).

57. Nadine Godehardt, "No End of History: A Chinese Alternative Concept of International Order?" SWP Research Paper, Berlin, January 2016, https://www.swp-berlin.org/fileadmin/.../ 2016RP02_gdh.pdf (accessed on 8 August 2016). 